\title{
Top Predators as Conservation Tools: Ecological Rationale, Assumptions, and Efficacy
}

\author{
Fabrizio Sergio, ${ }^{1}$ Tim Caro, ${ }^{2}$ Danielle Brown, ${ }^{2}$ \\ Barbara Clucas, ${ }^{2}$ Jennifer Hunter, ${ }^{2}$ James Ketchum, ${ }^{2}$ \\ Katherine McHugh, ${ }^{2}$ and Fernando Hiraldo ${ }^{1}$ \\ ${ }^{1}$ Department of Applied Biology, Estación Biológica de Doñana, CSIC, 41013 Seville, Spain; \\ email: fsergio@ebd.csic.es \\ ${ }^{2}$ Department of Wildlife, Fish \& Conservation Biology, University of California, Davis, \\ California 95616
}

\section{Key Words}

biodiversity, ecosystem conservation, surrogate species, trophic cascades, vertebrate predators

\begin{abstract}
We review the ecological rationale behind the potential compatibility between top predators and biodiversity conservation, and examine their effectiveness as surrogate species. Evidence suggests that top predators promote species richness or are spatio-temporally associated with it for six causative or noncausative reasons: resource facilitation, trophic cascades, dependence on ecosystem productivity, sensitivity to dysfunctions, selection of heterogeneous sites and links to multiple ecosystem components. Therefore, predator-centered conservation may deliver certain biodiversity goals. To this aim, predators have been employed in conservation as keystone, umbrella, sentinel, flagship, and indicator species. However, quantitative tests of their surrogate-efficacy have been astonishingly few. Evidence suggests they may function as structuring agents and biodiversity indicators in some ecosystems but not others, and that they perform poorly as umbrella species; more consensus exists for their efficacy as sentinel and flagship species. Conservation biologists need to use apex predators more cautiously, as part of wider, context-dependent mixed strategies.
\end{abstract}




\section{INTRODUCTION}

For millennia, top predators have inspired respect and admiration, being depicted as powerful, majestic, mysterious, beautiful, elusive, dangerous, rare, fierce, and secretive (Kruuk 2002). Conservation biologists have capitalized on such appeal and have used these species to lever public support for biodiversity preservation, raise funds, protect and restore ecosystems, prioritize reserve sites, and plan the size and configuration of protected areas (e.g., Gittleman et al. 2001, Ray 2005). The assumption behind all these objectives is usually that the conservation of a top predator automatically implies the preservation of the whole biological diversity of its supporting ecosystem (Simberloff 1998, Ray et al. 2005). However, such claims have been questioned recently for various reasons. First, some recent studies have found no association between top predators and biodiversity value (e.g., Andelman \& Fagan 2000, Kerr 1997, Ozaki et al. 2006). Secondly, despite their clear fundraising potential, the conservation of these species may impose high costs, such as livestock losses, missed revenue from resource exploitation, and even human deaths (Biles \& Noon 1990, Mishra 1997, Packer et al. 2005, Patterson et al. 2004). Such high costs may result in inefficient use of limited conservation funding and socio-economic conflict with humans, with consequent negative attitudes by local communities toward broader biodiversity issues (Linnell et al. 2000). Thirdly, the fact that some conservation organizations raise funds by using species known a priori to be glamorous may create a vicious cycle by which conservation targets are indirectly set by the public rather than being based on scientific criteria (Entwistle \& Dunstone 2000). The current debate on the controversial use of these species and the enormous financial investment dedicated annually to their protection calls for an urgent comprehensive assessment of their role and usefulness in the conservation arena. So far, such assessment has been conducted only for mammalian carnivores (Ray et al. 2005), which may or may not represent issues concerning top predatory species belonging to other taxa, such as raptors, sharks, or crocodiles.

Here, we review the assumptions and ecological rationale behind the supposed compatibility between top predators and biodiversity conservation. We then examine quantitative tests of their effectiveness as surrogate species in applied conservation. Specifically, we attempt to answer the following questions: Why should conservation plans based on top predators lead to broader biodiversity benefits? Why and how are apex predators used as surrogate species in conservation programs? What is the scientific, quantitative evidence so far for their efficiency as surrogates? Throughout, we use the term top or apex predator to refer to relatively large vertebrates that regularly feed on other vertebrates, including species such as mammalian carnivores, many cetaceans, diurnal and nocturnal raptors, seabirds, large lizards, crocodiles, and predatory fishes such as sharks. We recognize that this broad definition sometimes includes some medium-sized species, because sometimes such mesocarnivores may be more important as ecosystem structuring agents than locally larger predators, or may be functionally the only top predators left after the extirpation of larger species (e.g., Boutin 2005, Steneck \& Sala 2005). Unavoidably, most of the literature focuses on carnivores, raptors, and fishes, which are thus overrepresented in our assessment. However, whenever possible, we have tried to present examples and citations to cover as many different taxa as possible. Unless otherwise stated, biodiversity is expressed as species richness because this is how most researchers have measured it and how most conservation practitioners perceive it.

\section{ECOLOGICAL RATIONALE BEHIND THE LINK BETWEEN TOP PREDATORS AND BIODIVERSITY}

Conservation programs based on top predators may lead to broader biodiversity benefits for two main reasons: (a) the predators may directly cause high biodiversity, or (b) they may be 
spatio-temporally associated with it and thus act as indicators. Below, we review the ecological rationale behind both possibilities.

\section{Can Top Predators Cause High Biodiversity?}

There are two main ways in which top predators could directly promote high biodiversity: resource facilitation and trophic cascades. First, apex predators may facilitate resources essential to other species that are otherwise unavailable or scarcely available, such as carrion or safe breeding sites. For example, the reintroduction of wolves to Yellowstone promoted higher availability of carrion for scavengers (Wilmers et al. 2003a,b). In that study, wolves altered the spatio-temporal pattern of carrion availability, making it more uniform in time and space, and had pronounced effects on the scavenger assemblage (Wilmers et al. 2003a,b). Such facilitation-function was further shown to dampen the effects of climate change on the recipient species (e.g., Wilmers \& Getz 2005, Wilmers \& Post 2006, Sala 2006). Another way in which top predators provide essential resources is the frequently reported phenomenon of "breeding associations," in which a species subject to high predation pressure by species $X$ associates with predatory species $Y$ capable of killing or deterring species $X$. In such cases, top predators provide a "protective umbrella of enemy-free space" exploited by the associated species (e.g., Bogliani et al. 1999, Haemig 2001, Quinn \& Kokorev 2002). Finally, in some cases, top predators may function as "ecological engineers," such as when American alligators (Alligator mississippiensis) dig and maintain ponds that provide essential habitat for many species of fish, frogs, and snakes during dry periods in southern Florida (Craighead 1968).

Second, top predators may causally structure a whole community by initiating a trophic cascade, a series of interactions that "cascade through the community, transmitted by a chain of strongly interacting links" (Paine 1980, p. 674). In its simplest form, a cascade takes place when a consumer influences at least two other trophic levels, such as when a predator limits the populations of its prey, which in turn limits the populations of its own prey. Depending on the interaction strength of the species involved, this sequence of processes may cascade from top predators to primary producers, so that the predator indirectly structures the whole community. Therefore, for a cascade to happen, two conditions must be satisfied: (a) the top predator must be capable of limiting its prey populations and $(b)$ such effect is transmitted to even lower trophic levels. Below, we review the current evidence for both conditions in vertebrate communities.

Many experiments and correlative studies show that top predators in both terrestrial and aquatic environments may limit the populations of their prey below the level allowed by local carrying capacity (reviews in Carpenter \& Kitchell 1993, Newton 1998, Steneck \& Sala 2005). For example, predator removal experiments have shown that coyotes (Canis latrans) and lynx (Lynx canadensis) limit hare populations, raptors and mustelids limit vole populations, and wolves (Canis lupus) limit their ungulate prey (Hayes et al. 2003, Korpimäki et al. 2002, Krebs et al. 1995, Thirgood et al. 2000). Such effects may be direct, such as when the predator inflicts additive mortality, or indirect, such as when predation risk limits the space, habitat, or timeframes available for prey individuals (e.g., Berger et al. 2001, Ripple \& Beschta 2004a). However, in many cases prey populations are not limited by predation, or they are limited by predation only under certain circumstances. For example, analysis of recurrent events of extinction and recovery of sparrowhawk Accipiter nisus populations have not been followed by changes in their passerine prey (Newton et al. 1997), though both theoretical and empirical evidence suggests that predation limitation is context-dependent and more likely when prey populations are already at low levels from other causes (e.g., Bowyer et al. 2005, Mills 2005).

As for the second condition, evidence suggests that the prey species of top predators may in turn be strong interactors and exert top-down forcing on even lower trophic levels. For example, 
multiple studies have demonstrated the effects of ungulate browsing on species composition, nutrient cycling, and whole successional pathways of vegetation communities (e.g., Hobbs 1996, Molvar et al. 1993, Pastor et al. 1993). Similarly, small passerines were experimentally shown to be capable of limiting the populations of arthropod herbivores in oak woodlands, with consequent effects on leaf biomass (Marquis \& Whelan 1994). Finally, sea urchins may be capable of denuding whole seascapes originally occupied by kelp forests (reviews in Estes 2005 and Steneck \& Sala 2005). Therefore, at least in some circumstances, there is high potential for top predators to act as structuring agents. Below, we examine the cases in which complete cascades have been documented.

Trophic cascades initiated by top vertebrate predators are a common phenomenon in freshwater and marine ecosystems. Carpenter \& Kitchell (1993) and Steneck \& Sala (2005) provide extensive reviews with dozens of examples based on exclosure experiments and parallel monitoring of marine reserves and control sites before and after protection. Probably, the most famous example of an aquatic cascade is the one involving sea otters (Enhydra lustris), sea urchins, and kelp forests along the Pacific coasts of North America (review in Estes 2005). Sea otters, which prey heavily on sea urchins, were eradicated from vast coastal areas by the Pacific maritime fur trade. By comparing areas with and without otters and by following longitudinal cycles of recovery and subsequent extinction of sea otters for over 30 years, Estes and colleagues demonstrated how otter predation could limit herbivory by sea urchins, indirectly promoting the existence of widespread and structurally diverse kelp forests. In the absence of otters, sea urchins often increased to a point where kelp forests were rare or had completely disappeared. This process triggered diffuse indirect effects, thus influencing the whole seascape appearance, ecosystem productivity, nutrient cycling, growth rates of mussels and barnacles, densities of various fish species, and even the foraging tactics of other predators such as gulls. A final twist of the story came in the 1990s when sudden predation on sea otters by killer whales, Orcinus orca, probably triggered by fisheries' depletion of the killer whales' main prey, added a further top predator and trophic level to the system. As a result, otter populations declined, sea urchins increased and kelp forests deteriorated again (Estes et al. 1998). These results highlight the complexity and dynamic nature of the structuring force exerted by top predators.

Contrary to aquatic systems, debate exists over the prevalence of trophic cascades in terrestrial ecosystems (e.g., Pace et al. 1999, Strong 1992 and references therein). In Table 1, we list 15 cases initiated by a top predator. For example, by comparing islands with and without top predators in a Venezuelan lake, Terborgh et al. (2001) showed that predator extinction resulted in up to 100-fold increases in herbivore density, with consequent impacts on tree mortality and regeneration. Modeling of the dynamics of this system predicted a complete forest collapse in the near future on predator-free islands (review in Terborgh 2005). Various North American studies have reported cascades where top carnivores, such as wolf, cougar (Puma concolor), or grizzly bear (Ursus arctos), affect ungulate density and foraging patterns, with indirect, positive effects on plant species or communities (e.g., Berger et al. 2001, McLaren \& Peterson 1994, Ripple \& Beschta 2006). Effects of these cascades were shown to transmit to birds, amphibians, lizards, butterflies, and fish, and even to affect landscape structuring processes such as stream erosion (Berger et al. 2001, Ripple \& Beschta 2006). However, in other cases the effects are not so far reaching. For example, some cascades affect only some plant species and not others, with no overall effect on plant diversity, nor on other taxa such as squirrels or birds (Korpimäki et al. 2002, Krebs et al. 2001, Norrdahl et al. 2002); these have been defined as "species-cascades" as opposed to "community-cascades" (Schmitz et al. 2000).

Finally, a type of cascade of high conservation relevance is "mesopredator release" (Soulé et al. 1988), by which removal of a top predator causes an increase in mesopredators with consequent, detrimental effects on some prey populations. For example, in Doñana National Park (Spain) 
Table 1 Trophic cascades initiated by vertebrate top predators in terrestrial ecosystems ${ }^{a}$

\begin{tabular}{|c|c|c|c|c|c|c|c|}
\hline $\begin{array}{l}\text { Top predator } \\
\text { initiating the } \\
\text { cascade }\end{array}$ & & $\begin{array}{l}\text { Species negatively } \\
\text { affected in the } \\
\text { next trophic level }\end{array}$ & & $\begin{array}{l}\text { Species positively } \\
\text { affected in the next } \\
\text { trophic level }\end{array}$ & & $\begin{array}{c}\text { Indirect ecosystem } \\
\text { effects on: }\end{array}$ & Source \\
\hline $\begin{array}{l}\text { Wolf and } \\
\text { grizzly bear }\end{array}$ & $\rightarrow$ & Moose & $\rightarrow$ & $\begin{array}{l}\text { Riparian vegetation } \\
\text { (e.g., willow trees } \\
\text { and shrubs) }\end{array}$ & $\rightarrow$ & Riparian birds & Berger et al. 2001 \\
\hline Wolf & $\rightarrow$ & Moose & $\rightarrow$ & $\begin{array}{l}\text { Various shrub and } \\
\text { tree species }\end{array}$ & $\rightarrow$ & $\begin{array}{l}\text { Vegetation } \\
\text { composition }\end{array}$ & $\begin{array}{l}\text { McLaren \& } \\
\text { Peterson 1994b }\end{array}$ \\
\hline $\begin{array}{l}\text { Unspecified } \\
\text { vertebrate } \\
\text { top predators }\end{array}$ & $\rightarrow$ & $\begin{array}{l}\text { Pooled vertebrate } \\
\text { and invertebrate } \\
\text { herbivores }\end{array}$ & $\rightarrow$ & Pooled tree species & $\rightarrow$ & $\begin{array}{l}\text { Long-term forest } \\
\text { persistence }\end{array}$ & $\begin{array}{l}\text { Terborgh et al. } \\
2001\end{array}$ \\
\hline Cougar & $\rightarrow$ & Ungulate species & $\rightarrow$ & Riparian vegetation & $\rightarrow$ & $\begin{array}{l}\text { Stream bank erosion, } \\
\text { fishes, amphibians, } \\
\text { lizards, butterflies }\end{array}$ & $\begin{array}{l}\text { Ripple \& Beschta } \\
2006\end{array}$ \\
\hline Cougar & & Mule deer & & Black oak & & $\begin{array}{l}\text { Vegetation } \\
\text { recruitment rates }\end{array}$ & $\begin{array}{l}\text { Ripple \& Beschta } \\
2008\end{array}$ \\
\hline $\begin{array}{l}\text { Various } \\
\text { carnivores }\end{array}$ & $\rightarrow$ & Ungulate species & $\rightarrow$ & Various tree species & $\rightarrow$ & $\begin{array}{l}\text { Vegetation } \\
\text { recruitment rates }\end{array}$ & $\begin{array}{l}\text { Ripple \& Beschta } \\
\text { 2007a }\end{array}$ \\
\hline Wolf & $\rightarrow$ & Elk & $\rightarrow$ & Various tree species & $\rightarrow$ & $\begin{array}{l}\text { Vegetation } \\
\text { recruitment rates }\end{array}$ & $\begin{array}{l}\text { Ripple et al. } \\
\text { 2001; Ripple \& } \\
\text { Beschta 2003, } \\
\text { 2004b; Beschta } \\
\text { 2005; } 2007 \\
\end{array}$ \\
\hline Wolf & $\rightarrow$ & Elk & $\rightarrow$ & Aspen & $\rightarrow$ & $\begin{array}{c}\text { Vegetation } \\
\text { recruitment rates }\end{array}$ & $\begin{array}{l}\text { Beschta \& } \\
\text { Ripple } 2007\end{array}$ \\
\hline $\begin{array}{l}\text { Lynx and } \\
\text { coyote }\end{array}$ & $\rightarrow$ & Hares & $\rightarrow$ & $\begin{array}{c}\text { Voles, various plant } \\
\text { species }\end{array}$ & $\rightarrow$ & $-{ }^{c}$ & Krebs et al. 2001 \\
\hline Coyote & $\rightarrow$ & $\begin{array}{l}\text { Mammalian } \\
\text { mesopredators } \\
\text { (e.g., racoon) }\end{array}$ & $\rightarrow$ & Birds & $\rightarrow$ & Not tested & $\begin{array}{l}\text { Rogers \& } \\
\text { Caro } 1998\end{array}$ \\
\hline Coyote & $\rightarrow$ & $\begin{array}{l}\text { Mammalian } \\
\text { mesopredators }\end{array}$ & $\rightarrow$ & $\begin{array}{l}\text { Scrub-breeding } \\
\text { birds }\end{array}$ & $\rightarrow$ & Not tested & $\begin{array}{l}\text { Crooks \& } \\
\text { Soulé } 1999\end{array}$ \\
\hline Coyote & $\rightarrow$ & $\begin{array}{l}\text { Mammalian } \\
\text { mesopredators }\end{array}$ & $\rightarrow$ & Rodents & $\rightarrow$ & Not tested & $\begin{array}{l}\text { Henke \& } \\
\text { Bryant } 1999\end{array}$ \\
\hline Fox & $\rightarrow$ & Gulls & $\rightarrow$ & $\begin{array}{l}\text { Plant community } \\
\text { composition }\end{array}$ & $\rightarrow$ & $\begin{array}{c}\text { Nutrient subsidies } \\
\text { and ecosystem } \\
\text { productivity }\end{array}$ & Maron et al. 2006 \\
\hline Dingo & $\rightarrow$ & Feral cats and foxes & $\rightarrow$ & $\begin{array}{l}\text { Terrestrial } \\
\text { marsupials }\end{array}$ & $\rightarrow$ & Not tested & $\begin{array}{l}\text { Johnson et al. } \\
2006\end{array}$ \\
\hline $\begin{array}{l}\text { Raptors and } \\
\text { mustelids }\end{array}$ & $\rightarrow$ & Voles & $\rightarrow$ & Various plant species & $\rightarrow$ & $-^{c}$ & $\begin{array}{l}\text { Norrdahl et al. } \\
2002\end{array}$ \\
\hline
\end{tabular}

${ }^{a}$ For freshwater and marine ecosystems, Carpenter \& Kitchell (1993) and Steneck \& Sala (2005) report dozens of examples of cascades initiated by vertebrate top predators.

${ }^{\text {b }}$ See also McInnes et al. (1992).

'Significant impact on some species but not others, with no overall community-level or ecosystem-level effects ("species cascades," sensu Schmitz et al. 2000). 
both Iberian lynx (Lynx pardinus) and Egyptian mongoose (Herpestes ichneumon) prey on rabbits (Orictolagus cuniculus). However, lynx also kill mongooses, which accordingly avoid areas with lynx. As a result, mongooses take 5-10 times more rabbits in areas without lynx and rabbits are 2-4 times more abundant in areas with lynx (Palomares et al. 1995). In a similar vein, in the Alps, eagle owls (Bubo bubo) can depress the density of tawny owls (Strix aluco), which in turn are competitors and predators for other owl species. As a result, eagle owl abundance promotes higher diversity of the owl community, composed of many conservation-sensitive species (Sergio et al. 2007). A further example comes from Australia, where dingoes (Canis lupus dingo) limit the populations of introduced mesopredators such as feral cats (Felis catus) and foxes (Vulpes vulpes), which are capable of driving to extinction many species of native mammals. As a consequence, at a continent-wide scale, extinction rates of terrestrial marsupials are at minimum in areas with dingoes and maximum in areas from which dingoes have been extirpated (Johnson et al. 2006). Other clear examples of mesopredator release are given by Soulé et al. (1988), Rogers \& Caro (1998), Crooks \& Soulé (1999), and Roemer et al. (2002).

Overall, these findings demonstrate that trophic cascades do occur widely across realms, habitats, and continents and that, in these cases, the predators may constitute an evolutionary component essential to the integrity and stability of the ecosystem. However, caution should be used in assuming that top predators always have a structuring role, for the following reasons. (a) Top-down forcing is context-dependent and may be affected by carrying capacity, food web complexity, prey refugia, and human action (Bowyer et al. 2005, Ray 2005, Schmitz et al. 2000); it follows that cascades do not always happen. (b) Species cascades are probably more common than community cascades (Schmitz et al. 2000). Therefore, the capability of a top predator to trigger a cascade is no guarantee that this will affect the whole community or ecosystem. Most of the time it will affect only some species and not others. (c) Even when community cascades are in place, their outcome may be unexpected and sometimes undesirable. For example, killer whale predation on sea otters may indirectly disfavor the persistence of kelp forests, probably resulting in biodiversity-poor ecosystems (Estes et al. 1998). (d) Some species may be better than others as structuring agents and some species may exert top-down forcing at one site but not at other ones. For example, wolf reintroduction has produced pronounced community effects in the Yellowstone area but not in the eastern United States, where wolf populations will probably never reach a sufficiently high density to limit its prey because of human social issues (Berger \& Smith 2005, Ray 2005). (e) Similarly, many top predators are unlikely ever to regain the densities they once attained, because of widespread modification of ecosystems and conflict with humans. Therefore, their presence may frequently be more easily restored than their former densities and functional structuring role. These points suggest great caution in assuming that the protection or restoration of a top predator will automatically causally deliver broader ecosystem benefits.

\section{Spatio-Temporal Associations: Can Top Predators Indicate High Biodiversity?}

Top predators could be used in conservation even if they do not cause high biodiversity value, provided that they are spatially or temporally associated with it. For example, they could be used to identify sites in need of protection. There are various ecological reasons why we could expect top predators to be associated with biodiversity value. (a) Many studies have highlighted that the density of carnivores, raptors, and marine predators is often correlated with estimates of ecosystem productivity such as soil fertility, phosphorus levels in lakes, or the NDVI of vegetation productivity (Carroll et al. 2001, Newton et al. 1977, Seoane et al. 2003, Sergio et al. 2003, Worm et al. 2003). In turn, these ecosystem properties are usually strong predictors of biodiversity value (reviews in Gaston 1996, Rosenzweig 1995), which would provide a direct link between abundance 
of top predators and biodiversity. (b) Top predators are often sensitive to major ecosystem dysfunctions, such as chemical pollution, habitat alteration, fragmentation, and other anthropogenic disturbances that are likely to impact many different taxa and whole communities (see below, in the Section, Top Predators as Sentinel Species). (c) Apex predators often select sites with high topographical, habitat, and vegetational complexity (e.g., Carroll et al. 2001; Fernández et al. 2003; Hyrenbach et al. 2000; Klimley et al. 2003; Sergio et al. 2004a, 2006b), which frequently promotes high biodiversity (Gaston 1996, Rosenzweig 1995). (d) Most top predators have diets dominated by relatively few main prey species but include a large number of secondary prey species: richer (prey) communities will allow prey-switching during periods of scarcity of the main prey, ultimately favoring predator population persistence and linking predators to prey species diversity (e.g., Asseburg et al. 2006, Sinclair et al. 1998, Steenhof \& Kochert 1988). Furthermore, because each of these prey species in turn depends on a complex suite of biotic and abiotic conditions, the presence of a predator implies the persistence of such diffuse complexity. The above reasoning highlights an interesting and often discounted aspect: In many cases, top predators may need high biodiversity value and thus be associated with it in a bottom-up manner.

In conclusion, we have listed at least six causative or noncausative reasons that may justify a link between apex predators and biodiversity value: resource facilitation, trophic cascades, dependence on ecosystem productivity, sensitivity to dysfunctions, selection of heterogeneous sites, and extended links to many ecosystem components. Below, we review the evidence for the applied effectiveness of top predators as surrogate species.

\section{TOP PREDATORS AS SURROGATE SPECIES}

Surrogate species are most commonly classified as keystone, indicator, umbrella, sentinel, or flagship species (Caro \& O'Doherty 1999). Below, for each surrogate scheme, we (a) explain the rationale for using top predators within such a scheme; (b) report examples of their use; and (c) review quantitative tests of their effectiveness as such a surrogate.

\section{Top Predators as Keystone Species}

Keystone species are usually defined as those that have a disproportionate impact on the ecosystem relative to their abundance (Paine 1980, Simberloff 1998). We have already discussed the ecosystem structuring potential of top predators and the caveats involved. In applied programs, the keystone role of top predators is usually invoked as a way to achieve ecosystem restoration within reintroduction projects (e.g., Berger \& Smith 2005, Ray 2005, Soulé \& Noss 1998). As we have seen, such a function may be highly context-dependent and does not hold necessarily for all species; thus it should be invoked with great caution. Warren et al. (1990) highlight the danger of such an approach: The reintroduction of bobcats (Lynx rufus) was justified as a way to control high-density ungulate populations. One year after the release, the media contested the project because of the absence of the marketed effects on ungulates, and emphasis had to be switched to the intrinsic value of the predator as a restored ecosystem-component itself. Probably, the keystone role of top predators could be used more reliably as a conservation tool in aquatic ecosystems, where trophic cascades are more common.

\section{Top Predators as Biodiversity Indicators}

Above, we listed six reasons why top predators could be expected to indicate biodiversity value. Such a function has been usually employed in conservation programs to identify the location of areas in 
need of biodiversity protection, at sites as diverse as tropical woodland, temperate mountainous areas, or the ocean (e.g., Andelman \& Fagan 2000, Hooker \& Gerber 2004, Wikramanayake et al. 2002).

In Table 2 we list the studies that have explicitly examined the spatial link between the presence of top predators and biodiversity value. Surprisingly, we found only eight studies, which tested the hypothesis using 15 predatory species or pooled groups of species; all of them focussed on temperate areas, except for a study on jaguars in Belize. Furthermore, these studies used a very different suite of spatial scales, methods, sample sizes, data-sources, and estimates of biodiversity (Table 2), which makes cross comparisons quite difficult. For example, in some cases the identities of the predatory species were unspecified, some assessments were based on a single individual of the investigated predatory species, and in one case the analysis was restricted to threatened species both in terms of the predators involved and of the taxa used for the biodiversity assessment. Overall, only about half of the studies found a positive association and most of these centered on raptor species studied in the Alps, which makes it more difficult to extract any meaningful generalization.

It may be worth mentioning that other studies have reported positive relationships between the occurrence of a predator and the richness of its main prey taxa, the most common pattern being for higher richness of fish species recorded at lakes occupied by piscivorous raptors (Berkelman et al. 1999, Dzus \& Gerrard 1989, Sergio et al. 2003). However, because in such cases the predator is directly trophically linked to the richness estimate, it is unclear whether such a relationship extends also to other components of biodiversity. The importance of using biodiversity measures trophically "disconnected" from the predator has been highlighted by various researchers (e.g., Bifolchi \& Lode 2005; Sergio et al. 2005, 2006a).

Finally, some studies have included top predatory species in wider assessments of the role of surrogate species (e.g., Tognelli 2005, Williams et al. 2000). Unfortunately, researchers of such studies usually pool top predators and herbivores in the same test, obfuscating comparisons between the performance of upper and lower trophic-level species. In one such study, Williams et al. (2000) selected six bird and mammal species that, when combined, cooccurred with the greatest amount of biodiversity. This set of species included only one top predator: the barn owl (Tyto alba). In conclusion, given the paucity of studies and the disparity of their results, it is difficult to reach any general conclusion, except that in some cases top predators may be used as biodiversity indicators and in others they should not.

\section{Top Predators as Umbrella Species}

Top predators usually need large areas for foraging and breeding and are thus considered good umbrella species: the size, shape, and interconnectedness of protected areas, if planned on the basis of their exigent area requirements, is expected to encompass the requirements of less demanding species. The underlying assumption is that the population of the top predator in the reserve must be viable (i.e., its requirements fully met). In contrast to biodiversity indicators, which may help to select the location of a reserve, umbrella species can provide information on the size and configuration of protected areas. Top predators have been variously employed as umbrella species in conservation programs. For example, the Frontier Forest Initiative of the World Resources Institute identified intact forests on the basis of various criteria, one of which was a patch-size large enough to sustain viable populations of the largest local carnivores (Bryant et al. 1997). In other cases, park area has been increased to increase the viability of the populations of top predators, such as for bears in Austrian parks and Iberian lynx in Doñana National Park in Spain.

There have been few tests of the hypothesis that protecting viable populations of top predators will benefit other taxa. Noss et al. (1996) tested the umbrella species concept in Idaho using an 
Table 2 Published studies testing the spatial association between the presence of top predatory species and biodiversity value $^{\mathrm{a}}$

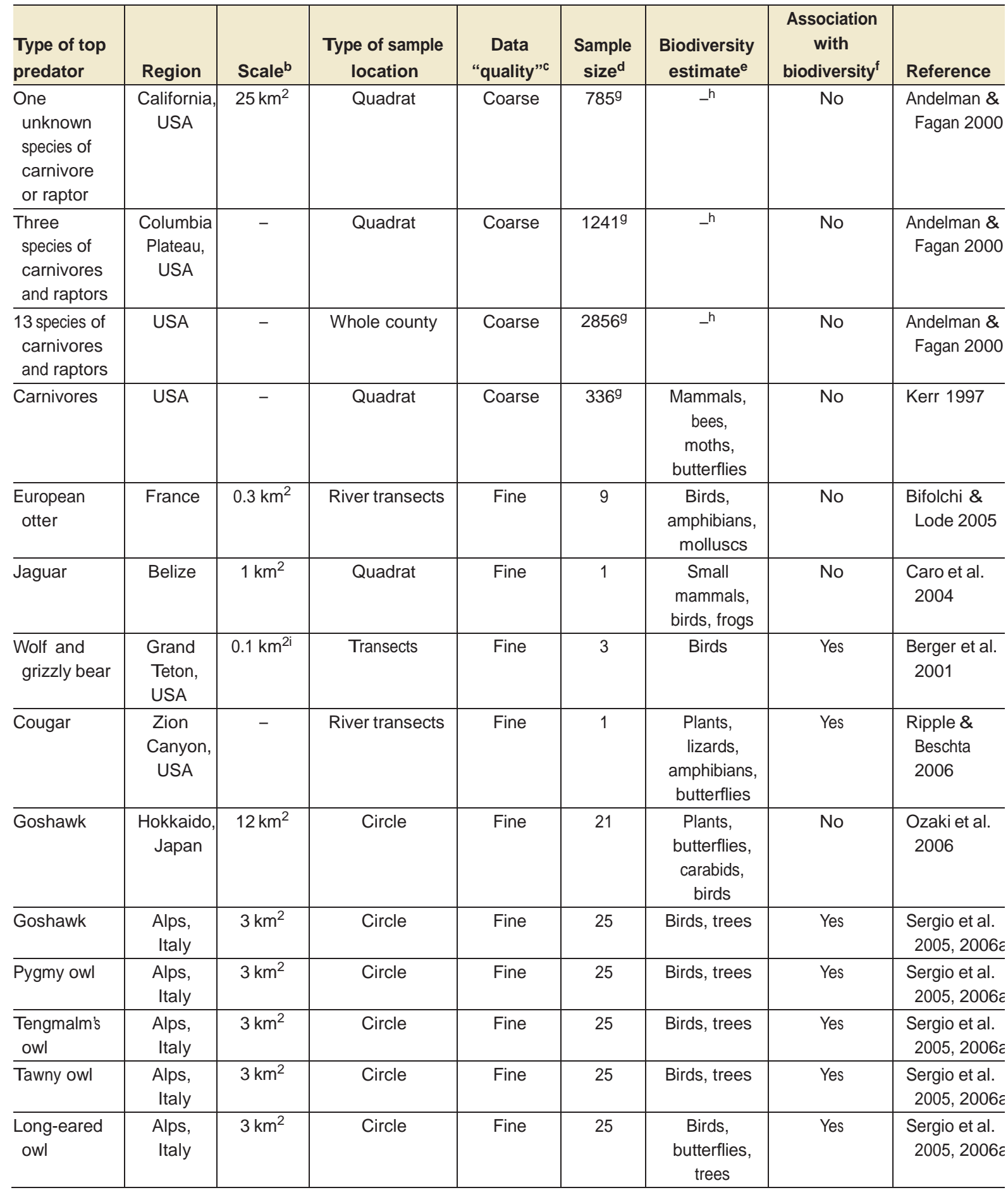




\begin{tabular}{|c|c|c|c|c|c|c|c|c|}
\hline $\begin{array}{l}\text { Type of top } \\
\text { predator }\end{array}$ & Region & Scale $^{\text {b }}$ & $\begin{array}{c}\text { Type of sample } \\
\text { location }\end{array}$ & $\begin{array}{c}\text { Data } \\
\text { "quality"c }\end{array}$ & $\begin{array}{l}\text { Sample } \\
\text { size }^{\text {d }}\end{array}$ & $\begin{array}{l}\text { Biodiversity } \\
\text { estimate }\end{array}$ & $\begin{array}{l}\text { Association } \\
\quad \text { with } \\
\text { biodiversity }\end{array}$ & Reference \\
\hline Scops owl & $\begin{array}{l}\text { Alps, } \\
\text { Italy }\end{array}$ & $3 \mathrm{~km}^{2}$ & Circle & Fine & 25 & $\begin{array}{c}\text { Birds, } \\
\text { butterflies, } \\
\text { trees }\end{array}$ & Yes & $\begin{array}{l}\text { Sergio et al. } \\
2005,2006\end{array}$ \\
\hline Eagle owl & $\begin{array}{l}\text { Alps, } \\
\text { Italy }\end{array}$ & $100 \mathrm{~km}^{2}$ & Quadrat & Coarse & 31 & $\begin{array}{c}\text { Birds, } \\
\text { amphibians, } \\
\text { reptiles }\end{array}$ & Yes & $\begin{array}{l}\text { Sergio et al. } \\
2004 a\end{array}$ \\
\hline
\end{tabular}

\footnotetext{
${ }^{a}$ Whenever possible, results are reported on a per species basis. To be conservative, we discounted studies in which biodiversity was only measured as the richness of the taxa that are also the main prey species for the predator (e.g., biodiversity only measured as the richness of fish species when the top predator is a piscivorous raptor, such as in Sergio et al. 2003). -, information not specified.

${ }^{b}$ Approximate size of the sample-unit at which biodiversity estimates were collected, such as an atlas-quadrat, or a circle around a nest site.

${ }^{c}$ Coarse, datasets based on mixed sources, including museum specimens or occasional sightings; Fine, datasets based on ad hoc surveys.

${ }^{\mathrm{d}}$ Number of sample locations occupied by the top predatory species.

${ }^{\mathrm{e}}$ Taxa employed as estimates of biodiversity value.

${ }^{f}$ Yes, top predator found to be positively associated with biodiversity; No, no significant associations between the two.

gOverall sample size of sites occupied or not by the top predators.

${ }^{\mathrm{h}}$ Assessment only restricted to an existing database of threatened species, without specifying the taxa.

'Based on three 100-m transects spaced $\geq 200 \mathrm{~m}$ apart (Berger et al. 2001).
}

action plan for grizzly bear conservation (using a population that was assumed to be viable) and distributions of terrestrial vertebrate species. They found that some taxa benefited from setting up reserves to protect the bears (e.g., birds and mammals) while others did not (e.g., reptiles). Similarly, Carroll et al. (2003) showed that the effectiveness of using population viabilities of a suite of large carnivores in the Rocky Mountains (United States and Canada) to determine the location and dimensions of reserves was variable depending on the nontarget taxon and degree of endemism. For example, the reserve network achieved the coverage of $50 \%$ of bird species, $27 \%$ of rare mammals, and $19 \%$ of nonvascular plants. Along the same lines, biodiversity levels did not vary between $13-\mathrm{km}^{2}$ areas used or not used by goshawks for foraging in Japan, the size of the areas being based on the average, local home range size of goshawks (Ozaki et al. 2006). On the contrary, higher biodiversity value was associated with larger expanses of habitat classified as suitable for eagle owls in the Alps, based on a validated habitat-selection model (Sergio et al. 2004a). Finally, different studies have shown that sites used by top marine predators for breeding and foraging overlap widely with biodiversity hotspots in the open oceans (Worm et al. 2003, 2005). Networks of marine reserves based on these areas could achieve high biodiversity coverage (Hooker \& Gerber 2004, Zacharias \& Roff 2001).

In conclusion, there has been little quantitative investigation of the effectiveness of top predators as umbrella species. The few results currently available are mixed and mostly show relatively low effectiveness of terrestrial predators as umbrellas, though their employment in marine environments seems more promising. From a qualitative point of view, it has been suggested that the umbrella role of top predators may be useful simply as a way to "think large," thus promoting large reserve size (Ray et al. 2005). The fact that larger areas support more species is a widely accepted pattern in ecology (reviews in Gaston 1996, Rosenzweig 1995).

\section{Top Predators as Sentinel Species}

Apex predators are often suggested as reliable sentinel species (also called "condition indicators") owing to their position at the top of the food chain and to a number of life history traits (low 
density, low fecundity, extended periods of juvenile dependence, etc.) that make them particularly vulnerable to human-induced alterations of their supporting ecosystems. For example, a group of carnivore species is employed as an early warning system of ecosystem dysfunctions within Canadian national parks, whereas sharks, whales, and seabirds are often used as indicator species in various marine parks and ecosystems (Boyd \& Murray 2001, Ray 2005).

Much evidence suggests that the sentinel role of predators is justified: (a) Top predatory species are usually the first to go extinct in a system, consistent with the idea of their higher sensitivity (Duffy 2002). (b) Many studies have demonstrated bioaccumulation of toxic pollutants along the food chain. The best example is surely the spectacular declines of numerous raptor species throughout Europe and North America in the 1950s-1970s caused by DDT and PCB contamination. This triggered extensive investigations, demonstration of wide-ranging effects on other taxa, and a subsequent ban on these products, known to be harmful also to human health (the "DDT saga," reviewed in Newton 1979). Other examples of sensitivity to toxic chemicals include sea otters and petroleum pollution; American alligators and heavy metals; and a large array of aquatic or marine predators known to be capable of pronounced bioaccumulation, such as polar bears (Ursus maritimus), dolphins, killer whales, herons, and seabirds (Bossert 2006, Burger \& Gochfeld 2004, Duvall \& Barron 2000, Jessup et al. 2004, Wells et al. 2004). (c) Top predators are often sensitive to human modifications of landscape structure and composition. Even if not all species are similarly affected and even if some may be more resilient than others or even favored by human-induced changes (Bird et al. 1996, Crooks 2002, Rodríguez-Estrella et al. 1998, Weaver et al. 1996), studies that have followed the whole landscape transformation process have usually reported profound community changes and progressive extirpation of many demanding species (e.g., Crooks 2002; Thiollay 1993, 2006). Ferguson \& Lariviere (2002) suggest ways to predict the identity of the most sensitive species in a predator community based on their life history traits. (d) Many top predatory species respond to vegetation structure within habitat patches, which is often determined by management regimes, such as silvicultural or agro-pastoral practices. These species have been frequently employed as management indicator species, such as American martens (Martes americana), goshawks (Accipiter gentilis), and spotted owls (Strix occidentalis) in the United States, Canada, and Japan (Hanley et al. 2005, Ozaki et al. 2006, Ray 2005). The rationale behind such a role is that management practices that affect these sensitive species also negatively affect other less demanding ones (a variant of the umbrella-concept). We are not aware of quantitative tests of this hypothesis. (e) Populations of top predators are often reported to respond to various ecosystem perturbations, often provoked by human action and besides those already detailed above. Examples include electrocution, eutrophication, unsustainable harvest of resources, excessive use of rodenticides, and poisoning campaigns (Pauly et al. 1998; Sergio et al. 2003, 2004b; Shore et al. 1999; Stone et al. 2003). The last are usually directed at mammalian carnivores and, being illegal, would be difficult to detect if they did not cause massive mortality of nontarget predatory species, such as raptors (Villafuerte et al. 1998). In this sense, top predators may help to uncover subtle ecosystem threats.

In conclusion, the sentinel role of many top predatory species has been widely demonstrated and seems promising. Some species may be particularly useful because they may function as early warning systems for contamination by chemicals that are harmful to many biota as well as humans (e.g., mercury, DDT, PCB). However, the efficacy of top predators as indicators of landscape degradation and management practices may be more conditional on the identity of the chosen species.

\section{Top Predators as Flagship Species}

Top predators feature prominently among flagship species owing to their inherent charismatic appearance and behavior. Conservation organizations use them extensively as poster species on 
campaign logos, magazine covers, and advertisements to attract funding and attention to a larger cause. For example, the jaguar was used as a symbol to promote a large-scale, crossnational conservation corridor that linked protected areas ranging from Mexico to Colombia ("Paseo Pantera") and received \$7.1 million US from the World Bank (World Bank 1997). On a smaller scale, in Florida, members of the public can pay extra for a panther-bearing license plate, the additional money being devoted to biodiversity conservation (Ray 2005, Simberloff 1998).

The high appeal that many top predators exert on the public has been well demonstrated in polls (e.g., Carvell et al. 1998, Leader-Williams \& Dublin 2000, Ray 2005). Probably, the best demonstration of the superior value of top predators as flagships is given by an assessment of the economic value assigned by U.K. citizens to a predator, the otter (Lutra lutra), and to an herbivore, the water vole (Arvicola terrestris) (White et al. 1997). Both species occupy the same habitat and are threatened by habitat change, fragmentation, and pollution. Interviewed people were willing to pay more for the otter ( $£ 11.9$ ) than for the water vole $(£ 7.4)$ and, even more surprisingly, they were willing to pay more for the otter alone than for the otter and water vole together ( $£ 10.9)$. Further demonstration of the enormous fundraising potential of some apex predators is shown by estimates of their economic value: a single lion (Panthera leo) in Amboseli National Park (Kenya) was worth $\$ 27,000$ US per year in visitor attraction and a leopard (Panthera pardus) in Londoloze Game Reserve (South Africa) was worth $\$ 50,000$ US per year, while the reintroduction of lions to Pilanesberg National Park (South Africa) would generate \$9 million US per year for the regional economy (Martin \& de Meulenaer 1988, McNeely 2000). Raptors also feature prominently as flagships: In the 1960s peregrine falcons (Falco peregrinus) became the icon of conservation campaigns against pesticides, while spotted owls are world renowned as poster species in campaigns to preserve old-growth forests (Newton 1979, Yaffee 1994).

Overall, few conservation biologists would doubt the fundraising potential of most mammal or avian top predatory species. Besides the economic gains, flagship predators are also ideal targets for education and dissemination, because the attention of a nonexpert audience is usually more easily captured by charismatic species than by difficult concepts such as functional biodiversity and ecosystem integrity (Entwistle \& Dunstone 2000, Ray 2005). However, there are circumstances in which these species should not be used, such as when they generate conflict with local communities because of human deaths, livestock losses, or other conflict situations (e.g., Linnell et al. 2000, 2005; Naughton-Treves et al. 2003; Woodroffe et al. 2005; Zimmermann et al. 2005).

\section{CONCLUSIONS}

In this review, we have outlined the rationale and efficacy of the employment of top predators in conservation biology and have been careful to separate conservation plans, projects, and investigations according to surrogate schemes. Overall, we found a mix of positive and negative support for their efficacy as surrogates, which is a common theme in most assessments of surrogate species, not just top predatory ones (e.g., Carignan \& Villard 2002, Caro \& O'Doherty 1999). For example, apex predators may function as structuring agents and biodiversity indicators in some ecosystems or regions but not in others, and there is little evidence for their umbrella role, while more consensus exists for their efficacy as sentinel and flagship species.

The most common pattern to emerge from this overview is probably that the efficacy of top predators as surrogates seems highly species- and context-dependent. Three examples may highlight the complex roles of these species: (a) in the Florida Everglades, American alligators create and maintain ponds that are essential habitat for other taxa; their nests, guarded against predators, offer safe breeding sites favored by turtles and snakes, which in turn are preyed upon by foraging alligators with indirect, positive effects on aquatic invertebrates, crayfish, frogs, salamanders, mice, 
and rats (Bondavalli \& Ulanowicz 1999). However, alligators may not be good flagship species and may create local conflict because of attacks on humans (Jacobsen \& Kushlan 1986). (b) Otters are good flagships and provide a reliable sentinel role against pollution but may not be reliable biodiversity indicators (Bifolchi \& Lode 2005, Mason 1996, White et al. 1997). (c) Lions are spectacular fund raisers, but their role as structuring agents is highly context-dependent; they can limit the populations of threatened mesocarnivores, and they sometimes generate extreme conflict with local communities because of human killings and livestock predation (Gittleman et al. 2001, McNeely 2000, Mills 2005, Packer et al. 2005). The context-dependence and species-dependence demonstrated above indicate the importance of locally tailored, cautious choices of top predatory species appropriate to the conservation task to be achieved. In this sense, the advantage of using top predators may lie in their frequent potential to adhere to various surrogate schemes, making them flexible tools. Under this scenario, conservation biologists could be seen as "talent scouts" or "trainers" who must identify the surrogate-potential of each species and use it or market it at its best depending on the socio-ecological context and target.

\section{Ways Forward}

Our review has uncovered an astonishing lack of quantitative studies testing the efficacy of top predators as surrogates. This is even more surprising when one considers that conservation has focused on these species for a century and annually entails enormous financial investments. In particular, there is an urgent need for studies on their structuring potential in terrestrial ecosystems and on their efficacy as local biodiversity indicators. The latter type of investigation could be easily incorporated as a pilot study into many conservation programs; it may be accomplished relatively quickly (Sergio et al. 2005, Ozaki et al. 2006), and it is needed to reach a consensus about how general is the pattern of spatial association with biodiversity value, a crucial and controversial issue currently based on a handful of studies. A further unexplored field is the use of species richness of a whole top predator assemblage as a biodiversity surrogate. This could be a promising measure because of the low species-redundancy of predator communities (Woodroffe \& Ginsberg 2005 ) and because the species richness of predator assemblages is commonly reported as a reliable predictor of the species richness of their prey communities (Begon et al. 1990).

Despite the mixed support for apex predators as surrogates, these species can still be used in conservation, albeit with more caution. Here, we list some conservation strategies that could incorporate top predators as useful surrogate species. (a) A focus on apex predators may be useful in promoting the idea of protection or management of large areas ("think large" hypothesis, see above). For example, Linnell et al. (2005) propose to use top predators for coarse-level, large-scale conservation planning. These large, interconnected areas and their matrix can then be managed at a finer scale on the basis of the ecological requirements of other species. (b) Top predators could be used as flagships for fund raising only after biodiversity targets have been decided on the basis of other criteria. For example, once an area is the target of protection based on a reserve selection algorithm applied to biodiversity measures, a charismatic predator present in the potential reserve could be used as a flagship for fund raising and education. (c) Top predators could be used as part of a set of surrogate species selected from as many trophic levels as possible (Hanley et al. 2005). The above proposals are in line with the increasing consensus about the efficacy of mixed strategies in conservation biology (e.g., Carignan \& Villard 2002, Entwistle \& Dunstone 2000, Groves 2003).

Finally, based on the issues raised by our overview, we list a series of criteria that could help to choose a candidate surrogate species among those available in the local predator community: (a) avoid species generating local conflict, unless this use is exclusively for fund raising operated at a distant location; (b) focus on species that are well-studied, easy to monitor, appeal to the 
public, and whose ecology is known in detail; (c) choose species with a varied diet (i.e., linked to many other ecosystem components) or specialized on herbivores that are likely to be keystone species for their ecosystem (e.g., voles in Fennoscandia, hares in boreal forests); ( $d$ ) select predators dependent on prey species with high interaction strength, such as ungulates capable of exerting strong browsing pressure or mesopredators known to prey on threatened birds; (e) at the same time, avoid top predators that may depress populations of other threatened species, such as lions in areas of sympatry with endangered cheetahs (Acinonyx jubatus) or wild dogs (Lycaon pictus); ( $f$ ) focus on species known to trigger a trophic cascade or hypothesized to do so, and include a follow-up plan to monitor community effects, as for the wolf reintroduction to Yellowstone (Berger \& Smith 2005); $(g$ ) if possible, use a threatened species or a species dependent on a threatened habitat and prey, so that its conservation may be useful anyway based on its intrinsic value.

In conclusion, and based on observations from the past 50 years, top predators will continue to be used extensively in conservation programs, especially because of their enormous potential as tools for fund raising and public relations. Our review has highlighted many gaps in our knowledge about the performance of such species and various examples of low efficiency, but also many circumstances in which these species may be extremely useful. Instead of passing from the idea of top predators as a "panacea" for biodiversity conservation to their complete dismissal because of some negative examples, the way forward may be to use them more cautiously and opportunistically, depending on local context, as part of wider mixed strategies and within an adaptive management approach.

\section{DISCLOSURE STATEMENT}

The authors are not aware of any biases that might be perceived as affecting the objectivity of this review.

\section{ACKNOWLEDGMENTS}

We thank L. Marchesi and A. Rodriguez for comments on a previous draft of the manuscript.

\section{LITERATURE CITED}

Andelman SJ, Fagan WF. 2000. Umbrellas and flagships: Efficient conservation surrogates or expensive mistakes? Proc. Natl. Acad. Sci. USA 97:5954-59

Asseburg C, Harwood J, Matthiopoulos J, Smout S. 2006. The functional response of generalist predators and its implications for the monitoring of marine ecosystems. In Top Predators in Marine Ecosystems, ed. I Boyd, S Wanless, CJ Camphuysen, pp. 262-74. Cambridge, UK: Cambridge Univ. Press

Begon M, Harper JL, Townsend CR. 1990. Ecology: Individuals, Populations and Communities. Oxford: Blackwell

Berger J, Smith DW. 2005. Restoring functionality in Yellowstone with recovering carnivores: gains and uncertainties. See Ray et al. 2005, pp. 100-9

Berger J, Stacey PB, Bellis L, Johnson MP. 2001. A mammalian predator-prey imbalance: grizzly bear and wolf extinction affect avian neotropical migrants. Ecol. Appl. 11:947-60

Berkelman J, Fraser JD, Watson RT. 1999. Lake selection by Madagascar fish-eagles. Auk 116:976-83

Beschta RL. 2005. Reduced cottonwood recruitment following extirpation of wolves in Yellowstone's northern range. Ecology 86:391-403

Beschta RL, Ripple WJ. 2007. Wolves, elk, and aspen in the winter range of Jasper National Park, Canada. Can. J. For. Res. 37:1873-85

Bifolchi A, Lode T. 2005. Efficiency of conservation shortcuts: an investigation with otters as umbrella species. Biol. Conserv. 126:523-27 
Biles CM, Noon BR. 1990. The Spotted Owl. UMAP J. 11:99-109

Bird DM, Varland DE, Negro JJ. 1996. Raptors in Human Landscapes: Adaptations to Built and Cultivated Environments. London: Academic

Bogliani G, Sergio F, Tavecchia G. 1999. Wood pidgeon nesting in association with hobby falcons: advantages and choice rules. Anim. Behav. 57:125-31

Bondavalli C, Ulanowicz RE. 1999. Unexpected effects of predators upon their prey: the case of the American Alligator. Ecosystems 2:49-63

Bossert GD. 2006. Marine mammals as sentinel species for oceans and human health. Oceanography 19:134-37

Boutin S. 2005. Top carnivores and biodiversity conservation in the boreal forest. See Ray et al. 2005, pp. $362-80$

Bowyer RT, Person DK, Pierce BM. 2005. Detecting top-down versus bottom-up regulation of ungulates by large carnivores: implications for conservation of biodiversity. See Ray et al. 2005, pp. 342-61

Boyd IL, Murray AWA. 2001. Monitoring a marine ecosystem using responses of upper trophic level predators. J. Anim. Ecol. 70:747-60

Bryant D, Nielse D, Tangley L. 1997. The Last Frontier Forests: Ecosystems and Economies on the Edge. Washington, DC: World Resour. Inst.

Burger J, Gochfeld M. 2004. Marine birds as sentinels of environmental pollution. EcoHealth 1:263-74

Carignan V, Villard M. 2002. Selecting indicator species to monitor ecological integrity: a review. Environ. Monit. Assess. 78:45-61

Caro T, Engilis A Jr, Fitzherbert E, Gardner T. 2004. Preliminary assessment of the flagship species concept at a small scale. Anim. Conserv. 7:63-70

Caro TM, O'Doherty G. 1999. On the use of surrogate species in conservation biology. Conserv. Biol. 13:80514

Carpenter SR, Kitchell JF, eds. 1993. The Trophic Cascade in Lakes. Cambridge, UK: Cambridge Univ. Press

Carroll C, Noss RF, Paquet PC. 2001. Carnivores as focal species for conservation planning in the Rocky Mountain region. Ecol. Appl. 11:961-80

Carroll C, Noss RE, Paquet PC, Schumaker NH. 2003. Use of population viability analysis and reserve selection algorithms in regional conservation plans. Ecol. Appl. 13:1773-89

Carvell C, Inglis NFJ, Mace GM, Purvis A. 1998. How Diana climbed the ratings at the zoo. Nature 395:213

Craighead FC. 1968. The role of the alligator in shaping plant communities and maintaining wildlife in the southern Everglades. Fla. Nat. 41:2-7, 69-74, 94

Crooks KR. 2002. Relative sensitivities of mammalian carnivores to habitat fragmentation. Conserv. Biol. $16: 488-502$

Crooks KR, Soulé ME. 1999. Mesopredator release and avifaunal extinctions in a fragmented system. Nature 400:563-66

Duffy JE. 2002. Biodiversity and ecosystem function: the consumer connection. Oikos 99:201-19

Duvall AE, Barron MG. 2000. A screening level probabilistic risk assessment of mercury in Florida Everglades food webs. Ecotoxicol. Environ. Saf. 47:298-305

Dzus EH, Gerrard JM. 1989. Interlake variations of bald eagle, Haliaeetus leucocephalus, populations in northcentral Saskatchewan. Can. Field Nat. 103:29-33

Entwistle A, Dunstone N, eds. 2000. Priorities for the Conservation of Mammalian Diversity: Has the Panda Had its Day? Cambridge, UK: Cambridge Univ. Press

Estes JA. 2005. Carnivory and trophic connectivity in kelp forests. See Ray et al. 2005, pp. 61-81

Estes JA, Tinker MT, Williams TM, Doak DF. 1998. Killer whale predation on sea otters linking oceanic and nearshore ecosystems. Science 282:473-76

Ferguson S, Lariviere S. 2002. Can comparing life histories help conserve carnivores? Anim. Conserv. 5:1-12

Fernández N, Delibes M, Palomares F, Mladenoff DJ. 2003. Identifying breeding habitat for the Iberian lynx: inferences from a fine-scale spatial analysis. Ecol. Appl. 13:1310-24

Gaston KJ, ed. 1996. Biodiversity: A Biology of Numbers and Difference. Oxford: Blackwell Sci.

Gittleman JL, Funk SM, Macdonald D, Wayne RK, eds. 2001. Carnivore Conservation. Cambridge, UK: Cambridge Univ. Press

Groves CR. 2003. Drafting a Conservation Blueprint: A Practitioner's Guide to Planning for Biodiversity. Washington, DC: Island Press 
Haemig PD. 2001. Symbiotic nesting of birds with formidable animals: a review with applications to biodiversity conservation. Biodivers. Conserv. 10:527-40

Hanley TA, Smith WP, Gende SM. 2005. Maintaining wildlife habitat in southeastern Alaska: implications of new knowledge for forest management and research. Landsc. Urban Plan. 72:113-33

Hayes RD, Farnell R, Ward RMP, Carey J, Dehn M, et al. 2003. Experimental reduction of wolves in the Yukon: ungulate responses and management implications. Wildl. Monogr. 152:1-35

Henke SE, Bryant FC. 1999. Effects of coyote removal on the faunal community in western Texas. J. Wildl. Manag. 63:1066-81

Hobbs NT. 1996. Modification of ecosystems by ungulates. J. Wildl. Manag. 60:695-713

Hooker SK, Gerber LR. 2004. Marine reserves as a tool for ecosystem-based management: the potential importance of megafauna. BioScience 54:27-39

Hyrenbach KD, Forney KA, Dayton PK. 2000. Marine protected areas and ocean basin management. Aquat. Conserv: Mar. Freshw. Ecosyst. 10:437-58

Jacobsen T, Kushlan JA. 1986. Alligators in natural areas: choosing conservation policies consistent with local objectives. Biol. Conserv. 36:181-96

Jessup DA, Miller M, Ames J, Harris M, Kreuder C, et al. 2004. Southern sea otter as a sentinel of marine ecosystem health. EcoHealth 1:239-45

Johnson CN, Isaac JL, Fisher DO. 2006. Rarity of a top predator triggers continent-wide collapse of mammalian prey: dingoes and marsupials in Australia. Proc. R. Soc. London Ser. B 274:341-46

Kerr JT. 1997. Species richness, endemism, and the choice of protected areas for conservation. Conserv. Biol. 11:1094-100

Klimley AP, Jorgensen SJ, Muhlia-Melo A, Beavers SC. 2003. The occurrence of yellowfin tuna (Thunnus albacares) at Espiritu Santo Seamount in the Gulf of California. Fish. Bull. 101:684-92

Korpimäki E, Norrdahl K, Klemola T, Pettersen T, Stenseth NC. 2002. Dynamic effects of predators on cyclic voles: field experimentation and model extrapolation. Proc. R. Soc. London Ser. B 269:991-97

Krebs CJ, Boutin S, Boonstra R, eds. 2001. Ecosystem Dynamics of the Boreal Forest: The Kluane Project. Oxford: Oxford Univ. Press

Krebs CJ, Boutin S, Boonstra R, Sinclair ARE, Smith JNM, et al. 1995. Impact of food and predation on the snowshoe hare cycle. Science 269:1112-15

Kruuk H. 2002. Hunter and Hunted: Relationships Between Carnivores and People. Cambridge, UK: Cambridge Univ. Press

Leader-Williams N, Dublin HT. 2000. Charismatic megafauna as "flagship species." See Entwistle \& Dunstone 2000, pp. 53-81

Linnel JDC, Promemberger C, Boitani L, Swenson JE, Breitenmoser U, Andersen R. 2005. The linkage between conservation strategies for large carnivores and biodiversity: the view from the "half-full" forests of Europe. See Ray et al. 2005, pp. 381-99

Linnell JDC, Swenson JE, Andersen R. 2000. Conservation of biodiversity in Scandinavian boreal forests: large carnivores as flagships, umbrellas, indicators, or keystones? Biodivers. Conserv. 9:857-68

Maron JL, Estes JA, Croll DA, Danner EM, Elmendorf SC, Buckelew SL. 2006. An introduced predator alters Aleutian island plant communities by thwarting nutrient subsidies. Ecol. Monogr. 76:3-24

Marquis RJ, Whelan CJ. 1994. Insectivorous birds increase growth of white oak through consumption of leaf-chewing insects. Ecology 75:2007-14

Martin RB, de Meulenaer T. 1988. Survey of the Status of the Leopard (Panthera pardus) in Sub-Saharan Africa. Lausanne: CITES Secr.

Mason CF. 1996. The Biology of Freshwater Pollution. Harlow: Longman

McInnes PF, Naiman RJ, Pastor J, Cohen Y. 1992. Effects of moose browsing on vegetation and litter of the boreal forest, Isle Royal, Michigan, USA. Ecology 73:2059-75

McLaren BE, Peterson RO. 1994. Wolves, moose and tree rings on Isle Royal. Science 266:1555-58

McNeely JA. 2000. Practical approaches for including mammals in biodiversity conservation. See Entwistle \& Dunstone 2000, pp. 355-67

Mills MGL. 2005. Large carnivores and biodiversity in African savanna ecosystems. See Ray et al. 2005, pp. 208-29 
Mishra C. 1997. Livestock depredation by large carnivores in the Indian trans-Himalaya: conflict perceptions and conservation projects. Environ. Conserv. 24:338-43

Molvar EM, Bowyer RT, Van Ballenberghe V. 1993. Moose herbivory, browse quality, and nutrient cycling in an Alaskan treeline community. Oecologia 94:472-79

Naughton-Treves L, Grossberg R, Treves A. 2003. Paying for tolerance: rural citizens' attitudes toward wolf depredation and compensation. Conserv. Biol. 17:1500-11

Newton I. 1979. Population Ecology of Raptors. Berkhamsted, UK: Poyser

Newton I. 1998. Population Limitation in Birds. London: Academic

Newton I, Dale L, Rothery P. 1997. Apparent lack of impact of Sparrowhawks on the breeding densities of some woodland songbirds. Bird Study 44:129-35

Newton I, Marquiss M, Weir DN, Moss D. 1977. Spacing of Sparrowhawk nesting territories. J. Anim. Ecol. 46:425-41

Norrdahl K, Klemola T, Körpimaki E, Koivula M. 2002. Strong seasonality may attenuate trophic cascades: vertebrate predator exclusion in boreal grassland. Oikos 99:419-30

Noss RF, Quigley HB, Hornocker MG, Merrill T, Paquet PC. 1996. Conservation biology and carnivore conservation in the Rocky Mountains. Conserv. Biol. 10:949-63

Ozaki K, Isono M, Kawahara T, Ida S, Kudo T, Fukuyama K. 2006. A mechanistic approach to evaluation of umbrella species as conservation surrogates. Conserv. Biol. 20:1507-15

Pace ML, Cole JJ, Carpenter SR, Kitchell JF. 1999. Trophic cascades revealed in diverse ecosystems. Trends Ecol. Evol. 14:483-88

Packer C, Ikanda D, Kissui B, Kushnir H. 2005. Lion attacks on humans in Tanzania. Nature 436:927-28

Paine RT. 1980. Food webs, linkage interaction strength, and community infrastructure. J. Anim. Ecol. 49:66785

Palomares F, Gaona P, Ferreras P, Delibes M. 1995. Positive effects on game species of top predators by controlling smaller predator populations: an example with lynx, mongooses, and rabbits. Conserv. Biol. 9:295-305

Pastor J, Dewey B, Naiman RJ, McInnes PF, Cohen Y. 1993. Moose browsing and soil fertility of Isle Royal National Park. Ecology 74:467-80

Patterson BD, Kasiki SM, Selempo E, Kays RW. 2004. Livestock predation by lions (Panthera leo) and other carnivores on ranches neighbouring Tsavo National Parks, Kenya. Biol. Conserv. 119:507-16

Pauly D, Christensen V, Dalsgaard J, Froese R, Torres F Jr. 1998. Fishing down marine food webs. Science 279:860-63

Quinn JL, Kokorev Y. 2002. Trading-off risks from predators and from aggressive hosts. Behav. Ecol. Sociobiol. 51:455-60

Ray JC. 2005. Large carnivorous animals as tools for conserving biodiversity: assumptions and uncertainties. See Ray et al. 2005, pp. 34-56

Ray JC, Redford KH, Steneck RS, Berger J, eds. 2005. Large Carnivores and the Conservation of Biodiversity. Washington, DC: Island Press

Ripple WJ, Beschta RL. 2003. Wolf reintroduction, predation risk, and cottonwood recovery in Yellowstone National Park. For. Ecol. Manag. 184:299-313

Ripple WJ, Beschta RL. 2004a. Wolves and the ecology of fear: can predation risk structure ecosystems? BioScience 54:755-66

Ripple WJ, Beschta RL. 2004b. Wolves, elk, willows, and trophic cascades in the upper Gallatin Range of Southwestern Montana, USA. For. Ecol. Manag. 200:161-81

Ripple WJ, Beschta RL. 2006. Linking a cougar decline, trophic cascade, and catastrophic regime shift in Zion National Park. Biol. Conserv. 133:397-408

Ripple WJ, Beschta RL. 2007a. Hardwood tree decline following large carnivore loss on the Great Plains, USA. Front. Ecol.. 5:241-46

Ripple WJ, Beschta RL. 2007b. Restoring Yellowstone's aspen with wolves. Biol. Conserv. 138: 514-19

Ripple WJ, Beschta RL. 2008. Trophic cascades involving cougar, mule deer, and black oaks in Yosemite National Park. Biol. Conserv. 141:1249-56

Ripple WJ, Larsen EJ, Renkin, RA, Smith DW. 2001. Trophic cascades among wolves, elk and aspen on Yellowstone National Park's northern range. Biol. Conserv. 102:227-34 
Rodríguez-Estrella R, Donázan JA, Hiraldo F. 1998. Raptors as indicators of environmental change in the scrub habitat of Baja California Sur, Mexico. Conserv. Biol. 12:921-25

Roemer GW, Donlan CJ, Courchamp F. 2002. Golden eagles, feral pigs, and insular carnivores: how exotic species turn native predators into prey. Proc. Natl. Acad. Sci. USA 99:791-96

Rogers CM, Caro MJ. 1998. Song sparrows, top carnivores, and nest predation: a test of the mesopredator release hypothesis. Oecologia 116:227-33

Rosenzweig ML. 1995. Species Diversity in Space and Time. Cambridge, UK: Cambridge Univ. Press

Sala E. 2006. Top predators provide insurance against climate change. Trends Ecol. Evol. 21:479-80

Schmitz OJ, Hambäck PA, Beckerman AP. 2000. Trophic cascades in terrestrial ecosystems: a review of the effects of carnivore removals on plants. Am. Nat. 155:141-53

Seoane J, Viñuela J, Díaz-Delgado R, Bustamante J. 2003. The effects of land use and climate on red kite distribution in the Iberian peninsula. Biol. Conserv. 111:401-14

Sergio F, Marchesi L, Pedrini P. 2003. Reconciling the dichotomy between single species and ecosystem conservation: black kites (Milvus migrans) and eutrophication in pre-Alpine lakes. Biol. Conserv. 110:10111

Sergio F, Marchesi L, Pedrini P. 2004a. Integrating individual habitat choices and regional distribution of a biodiversity indicator and top predator. J. Biogeogr. 31:619-28

Sergio F, Marchesi L, Pedrini P, Ferrer M, Penteriani V. 2004b. Electrocution alters the distribution and density of a top predator, the eagle owl Bubo bubo. J. Appl. Ecol. 41:836-45

Sergio F, Marchesi L, Pedrini P, Penteriani V. 2007. Coexistence of a generalist owl with its intraguild predator: distance-sensitive or habitat-mediated avoidance? Anim. Behav. 74:1607-16

Sergio F, Newton I, Marchesi L. 2005. Top predators and biodiversity. Nature 236:192

Sergio F, Newton I, Marchesi L, Pedrini P. 2006a. Ecologically justified charisma: preservation of top predators delivers biodiversity conservation. J. Appl. Ecol. 43:1049-55

Sergio F, Pedrini P, Rizzolli F, Marchesi L. 2006b. Adaptive range selection by golden eagles in a changing landscape: a multiple modelling approach. Biol. Conserv. 133:32-41

Shore RF, Birks JDS, Freestone P. 1999. Exposure of nontarget vertebrates to second-generation rodenticides in Britain, with particular reference to the polecat Mustela putorius. N. Z. J. Ecol. 23:199-206

Simberloff D. 1998. Flagships, umbrellas, and keystones: is single-species management passé in the landscape era? Biol. Conserv. 83:247-57

Sinclair ARE, Pech RP, Dickman CR, Hik D, Mahon P, Newsome AE. 1998. Predicting effects of predation on conservation of endangered prey. Conserv. Biol. 12:564-75

Soulé ME, Bolger DT, Alberts AC, Sauvajot R, Wright J, et al. 1988. Reconstructed dynamics of rapid extinctions of chaparral-requiring birds in urban habitat islands. Conserv. Biol. 2:75-92

Soulé ME, Noss R. 1998. Rewilding and biodiversity: complementary goals for continental conservation. Wild Earth 8:19-27

Steenhof K, Kochert MN. 1988. Dietary responses of three raptor species to changing prey densities in a natural environment. J. Anim. Ecol. 57:37-48

Steneck RS, Sala E. 2005. Large marine carnivores: trophic cascades and top-down controls in coastal ecosystems past and present. See Ray et al. 2005, pp. 110-37

Stone WB, Okoniewski JC, Stedelin JR. 2003. Anticoagulant rodenticides and raptors: recent findings from New York, 1998-2001. Bull. Environ. Contam. Toxicol. 70:34-40

Strong DR. 1992. Are trophic cascades all wet? Differentiation and donor-control in speciose ecosystems. Ecology 73:747-54

Terborgh J. 2005. The green world hypothesis revisited. See Ray et al. 2005, pp. 82-99

Terborgh J, Lopez L, Nunez P, Rao M, Shahabuddin G, et al. 2001. Ecological meltdown in predator-free forest fragments. Science 294:1923-26

Thiollay JM. 1993. Response of a raptor community to shrinking area and degradation of tropical rainforest in the south Ghats (India). Ecography 16:97-110

Thiollay JM. 2006. The decline of raptors in west Africa: long-term assessment and the role of protected areas. Ibis 148:240-54

Thirgood S, Redpath S, Newton I, Hudson P. 2000. Raptors and red grouse: conservation conflicts and management solutions. Conserv. Biol. 14:95-104 
Tognelli MF. 2005. Assessing the utility of indicator groups for the conservation of South American terrestrial mammals. Biol. Conserv. 121:409-15

Villafuerte R, Viñuela J, Blanco JC. 1998. Extensive predator persecution caused by population crash in a game species: the case of red kites and rabbits in Spain. Biol. Conserv. 84:181-88

Warren RJ, Conroy CJ, James WE, Baker LA, Diefenbach DR. 1990. Reindroduction of bobcats on Cumberland Island, Georgia: a biopolitical lesson. Trans. N. Am. Wildl. Nat. Resour. Conf. 55:580-89

Weaver JL, Paquet PC, Ruggiero LF. 1996. Resilience and conservation of large carnivores in the Rocky Mountains. Conserv. Biol. 10:964-76

Wells RS, Rhinehart HL, Hansen LJ, Sweeney JC, Townsend FI, et al. 2004. Bottlenose dolphins as marine ecosystem sentinels: developing a health monitoring system. EcoHealth 1:246-54

White PCL, Gregory KW, Lindley PJ, Richards G. 1997. Economic values of threatened mammals in Britain: a case study of the otter Lutra lutra and the water vole Arvicola terrestris. Biol. Conserv. 82:345-54

Wikramanayake E, Dinerstein E, Loucks CJ, Olson DM, Morrison J, et al. 2002. Terrestrial Ecoregions of the Indo-Pacific: A Conservation Assessment. Washington, DC: Island Press

Williams PH, Burgess ND, Rahbek C. 2000. Flagship species, ecological complementarity and conserving the diversity of mammals and birds in sub-Sahara Africa. Anim. Conserv. 3:249-60

Wilmers CC, Crabtree RL, Smith DW, Murphy KM, Getz WM. 2003a. Trophic facilitation by introduced top predators: grey wolf subsidies to scavengers in Yellowstone National Park. J. Anim. Ecol. 72:909-16

Wilmers CC, Getz WM. 2005. Gray wolves as climate change buffers in Yellowstone. PLoS Biol. 3(4):e92

Wilmers CC, Post E. 2006. Predicting the influence of wolf-provided carrion on scavenger community dynamics under climate change scenarios. Glob. Change Biol. 12:403-9

Wilmers CC, Stahler DR, Crabtree RL, Smith DW, Getz WM. 2003b. Resource dispersion and consumer dominance: scavenging at wolf- and hunter-killed carcasses in Greater Yellowstone, USA. Ecol. Lett. 6:996-1003

Woodroffe R, Ginsberg JR. 2005. King of the beasts? Evidence for guild redundancy among large mammalian carnivores. See Ray et al. 2005, pp. 154-75

Woodroffe R, Thirgood S, Rabinowitz A. 2005. People and Wildlife: Conflict or Coexistence? Cambridge, UK: Cambridge Univ. Press

World Bank. 1997. Nicaragua Atlantic Biological Corridor Project. Proj. Doc. Washington, DC: World Bank

Worm B, Lotze HK, Myers RA. 2003. Predator diversity hotspots in the blue ocean. Proc. Natl. Acad. Sci. USA 100:9884-88

Worm B, Sandow M, Oschlies A, Lotze HK, Myers RA. 2005. Global patterns of predator diversity in the open oceans. Science 309:1365-69

Yaffee SL. 1994. The Wisdom of the Spotted Owl: Policy Lessons for a New Century. Washington, DC: Island Press

Zacharias MA, Roff JC. 2001. Use of focal species in marine conservation and management: a review and critique. Aquat. Conserv.: Mar. Freshw. Ecosyst. 11:59-76

Zimmermann A, Walpole MJ, Leader-Williams N. 2005. Cattle ranchers' attitudes to conflicts with jaguars in the Pantanal of Brazil. Oryx 39:406-12 
Top Predators as Conservation Tools: Ecological Rationale, Assumptions, and Efficacy

Fabrizio Sergio, Tim Caro, Danielle Brown, Barbara Clucas, Jennifer Hunter,

James Ketchum, Katherine McHugh, and Fernando Hiraldo!!!!!!!!!!!!!!!!!!!!!!!!!! 1

Revisiting the Impact of Inversions in Evolution: From Population

Genetic Markers to Drivers of Adaptive Shifts and Speciation?

Ary A. Hoffmann and Loren H. Rieseberg !!!!!!!!!!!!!!!!!!!!!!!!!!!!!!!!!!!!!!!21

Radial Symmetry, the Anterior/Posterior Axis, and Echinoderm Hox Genes

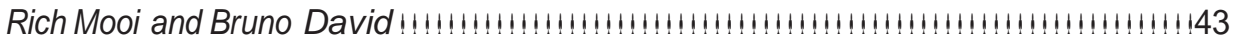

The Great American Schism: Divergence of Marine Organisms After the Rise of the Central American Isthmus

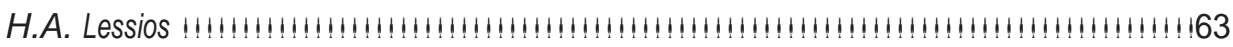

The Ecological Performance of Protected Areas

Kevin J. Gaston, Sarah F. Jackson, Lisette Cantú-Salazar,

and Gabriela Cruz-Piñón !!!!!!!!!!!!!!!!!!!!!!!!!!!!!!!!!!!!!!!!!!!!!!!!!!!!!!!!!93

Morphological Integration and Developmental Modularity

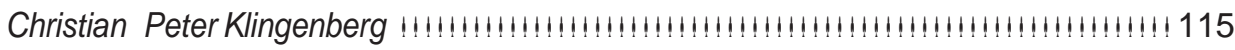

Herbivory from Individuals to Ecosystems

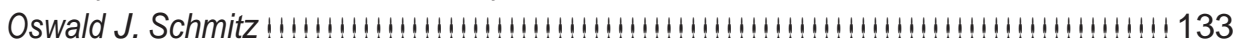

Stoichiometry and Nutrition of Plant Growth in Natural Communities

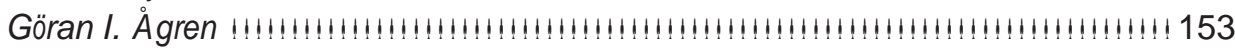

Plague Minnow or Mosquito Fish? A Review of the Biology and Impacts of Introduced Gambusia Species

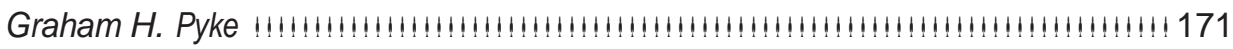

The Impact of Natural Selection on the Genome: Emerging Patterns in Drosophila and Arabidopsis

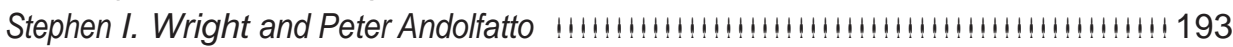


Sanctions, Cooperation, and the Stability of Plant-Rhizosphere Mutualisms

E. Toby Kiers and R. Ford Denison !!!!!!!!!!!!!!!!!!!!!!!!!!!!!!!!!!!!!!!!!!!!!!!!!!!!! 215

Shade Tolerance, a Key Plant Feature of Complex Nature and Consequences

Fernando Valladares and Ülo Nïnemets

The Impacts of Fisheries on Marine Ecosystems and the Transition to Ecosystem-Based Management

Larry B. Crowder, Elliott L. Hazen, Naomi Avissar, Rhema Bjorkland, Catherine Latanich, and Matthew B. Ogburn!!!!!!!!!!!!!!!!!!!!!!!!!!!!!!!!!!!!! 259

The Performance of the Endangered Species Act

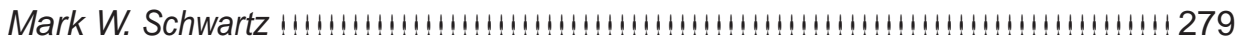

Phylogenetic Approaches to the Study of Extinction

Andy Purvis !!!!!!!!!!!!!!!!!!!!!!!!!!!!!!!!!!!!!!!!!!!!!!!!!!!!!!!!!!!!!!!!!!!! 301

Adaptation to Marginal Habitats

Tadeusz J. Kawecki !!!!!!!!!!!!!!!!!!!!!!!!!!!!!!!!!!!!!!!!!!!!!!!!!!!!!!!!!!!!!!! 321

Conspecific Brood Parasitism in Birds: A Life-History Perspective

Bruce E. Lyon and John McA. Eadie !!!!!!!!!!!!!!!!!!!!!!!!!!!!!!!!!!!!!!!!!!!!!!!!!! 343

Stratocladistics: Integrating Temporal Data and Character Data in Phylogenetic Inference

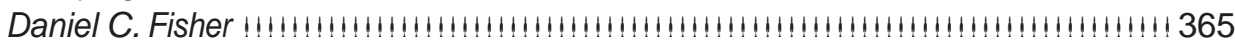

The Evolution of Animal Weapons

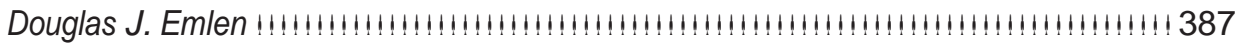

Unpacking $\beta$ : Within-Host Dynamics and the Evolutionary Ecology of Pathogen Transmission

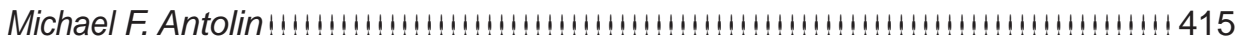

Evolutionary Ecology of Figs and Their Associates: Recent Progress and Outstanding Puzzles

Edward Allen Herre, K. Charlotte Jandér, and Carlos Alberto Machado !!!!!!!!!!!!!!! 439

The Earliest Land Plants

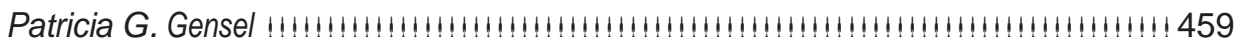

Spatial Dynamics of Foodwebs

Priyanga Amarasekare !!!!!!!!!!!!!!!!!!!!!!!!!!!!!!!!!!!!!!!!!!!!!!!!!!!!!!!!!!!!!! 479

Species Selection: Theory and Data

David Jablonski!!!!!!!!!!!!!!!!!!!!!!!!!!!!!!!!!!!!!!!!!!!!!!!!!!!!!!!!!!!!!!!!!!!!!!!!!!!!!!501 
New Answers for Old Questions: The Evolutionary Quantitative

Genetics of Wild Animal Populations

Loeske E.B. Kruuk, Jon Slate, and Alastair J. Wilson !!!!!!!!!!!!!!!!!!!!!!!!!!!!!! 525

Wake Up and Smell the Roses: The Ecology and Evolution of Floral Scent

Robert A. Raguso !!!!!!!!!!!!!!!!!!!!!!!!!!!!!!!!!!!!!!!!!!!!!!!!!!!!!!!!!!!!!!!!!! 549

Ever Since Owen: Changing Perspectives on the Early Evolution of Tetrapods

Michael I. Coates, Marcello Ruta, and Matt Friedman !!!!!!!!!!!!!!!!!!!!!!!!!!! 571

Pandora's Box Contained Bait: The Global Problem of Introduced

Earthworms

Paul F. Hendrix, Mac A. Callaham, Jr., John M. Drake, Ching-Yu Huang,

Sam W. James, Bruce A. Snyder, and Weixin Zhang !!!!!!!!!!!!!!!!!!!!!!!!!!!!!!!!!!! 593

Trait-Based Community Ecology of Phytoplankton

Elena Litchman and Christopher A. Klausmeier !!!!!!!!!!!!!!!!!!!!!!!!!!!!!!!!!!!! 615

What Limits Trees in $\mathrm{C}_{4}$ Grasslands and Savannas?

William J. Bond !!!!!!!!!!!!!!!!!!!!!!!!!!!!!!!!!!!!!!!!!!!!!!!!!!!!!!!!!!!!!!!!! 641

\section{Indexes}

Cumulative Index of Contributing Authors, Volumes 35-39!!!!!!!!!!!!!!!!!!!!!!!! 661

Cumulative Index of Chapter Titles, Volumes 35-39 !!!!!!!!!!!!!!!!!!!!!!!!!!!!!!!!! 665

\section{Errata}

An online log of corrections to Annual Review of Ecology, Evolution, and Systematics articles may be found at http://ecolsys.annualreviews.org/errata.shtml 